\title{
A METHODOLOGICAL MODEL FOR MONITORING URBAN GROWTH: EXAMPLE OF THE METROPOLITAN AREA OF TUNIS (MAT)
}

\author{
Hisham M A.. Gadou, \\ Associate Professor, Ain Shams Uni. Faculty of Engineering, Dept. of \\ Urban Design \& Planning, Cairo, Egypt \\ E-mail: hishgadou08@gmail.com
}

(Received December13, 2008 Accepted January 24, 2009)

\begin{abstract}
Urbanization process is a major factor of change in the Mediterranean region where pre-urban cities and new urban settlements have raised over the past decades. Several cities rapidly became regional centres or international nodes according to economic and political pressures. Urbanization (and informal settlement) causes land cover changes which can lead to deeper social, economic and environmental changes. The main objective of this paper is to provide time-series information to define and locate the evolution trends of the Tunis Metropolitan Area.

In a first step, satellite imagery has been used (1986-1996 SPOT XS) to extract the land cover, identify the urbanization processes and estimate the changes. One of the main aspects is to locate informal settlement areas that grow significantly along the roadway networks in the Tunisian capital. Results show a global progression of the built-up areas of $13 \%$ in 10 years. In a second step, the urban growth evolution has been approached by using a potential model that provides general trends of feasible urban expansion, taking into account protection laws of natural and agricultural land. This type of model has not been tested on developing cities and as such it corresponds to a new planning contribution for planners who have no concept of spatially how their urban areas have changed over time and where the growth is occurring. In this case, it has been calibrated over the period of 1986-1996, and then applied to predict the location of the built-up growth over the next 10 years (1996 - 2006). These results can provide local authorities and other stakeholders with information towards decision support documents for future planning and monitoring plans. Moreover, they can be updated systematically through the integration of remote sensing data.
\end{abstract}

KEYWORDS: Urban growth; Land cover changes; Remote sensing data; Potential model

\section{INTRODUCTION}

Urbanization is a major trend in recent years all around the world. The concept of urbanization can vary from author to author; here, it is defined as a territorial and socioeconomic process that induces a general transformation of land cover/use categories. Referring to French or US census, urbanization process deals with 
concentrations of population and activities. It creates aggregations of urban areas that shelter hundreds of thousands of inhabitants. From an economic point of view, these structures are more and more linked with international activities, becoming an interface between local and national scales, and the international one.

However, this situation is heterogeneous all around the globe. Rapid urbanization is often the cause of enormous pressure on rural and natural environments. In 1920, the urban population made up $14 \%$ of the world. It reached 25\% in 1950. Between 1950 and 1985, the number almost tripled [41]. Older industrial cities seem less affected by these trends of population increase as the rate of rural-tourban migration has reached stabilization. More spectacular situations are noticeable in developing countries where a large number of cities housing millions are located. The rate of urban population growth between 1950 and 1990 has been much faster in developing countries, from $17 \%$ to $34 \%$ and the rural-to-urban migration is still significant.

Continuous migration flows have largely contributed to an increase of the builtup areas. One of the main effects of such a situation is the transformation of settlement structures. Therefore, urbanization has been studied more in the last few decades because of the increasing interest in environmental issues. Since the Stockholm Conference on human environment (1972) and continuing now, scientists, planners and researchers have paid much more attention to the issues of land cover changes [6]; [28]; [34]; [40]. But as Bounfour noted, "our inability to monitor land cover changes in a consistent way over the long term is a serious limitation in our capacity to understand the driving forces and processes controlling these changes" [4].

Indeed, urban changes are often associated with specific situations regarding cadastre, legacy rules, planning decisions, lack of dwellings, etc. In this context, a significant portion of the growth takes the form of informal settlements that are one of the more common types of built-up practices. By definition, these areas are largely unplanned and typically there are no maps indicating the positions and patterns of shacks and building [36]. They are the result of an urgent need for shelter by the less-favored urban population and can be characterized by a dense proliferation of small shelters [29].

It is important to better understand the driving forces and processes of urban changes because of the dissemination of such habitats around central cities mainly out of official planning sectors, without legal existence (and consequently without legal access to city services and without environmental conservation rules, etc.). In fact, one of the difficulties is to embrace the total area where urban changes may appear, and to appreciate the intensity of these changes. Moreover, boundaries between urban and rural areas tend to disappear with settlements being more and more scattered all around the main cities. Hence, monitoring urban changes implies the consideration of two key points: the forecast of the amount of changes and the location of future built-up areas. This information is extremely valuable to urban planners, who use this spatial information to be able to monitor the impact of this growth (often accompanied by poverty, homelessness, crime, poor physical health, social instability and environmental degradation), but also to evaluate existing urban policies and develop appropriate responses or strategies. In this context, this paper presents a time-series analysis using remotely sensed data (Spot images) to identify urban changes over a 
decade on the region of Tunis (capital of Tunisia, in the Mediterranean countries). The Metropolitan Area of Tunis (MAT) is interesting because it had to face the uncontrolled development of informal settlements, especially in its southwestern part. More precisely, the paper focuses on the localization and the quantification of the urban built-up extension (informal settlements) on rural and natural areas. A potential model is applied to locate major trends of urban extension. In a first step, the land cover changes are identified over the period 1986-1996. In a second step, the forthcoming extension in the following decade (1996-2006) is modeled by using the trends of real expansion of built-up areas.

It must be noted here that the merit of this paper lies in the way it explains the method of using satellite imagery in detecting, recording, tracking and monitoring changes in the extent and direction of ground cover over a period of time. This paper does not claim that the information it provides represent the latest picture of the reality on the ground. It only shows how the methodology can be used to obtain the most current picture of any land form, built-up area, land covered by any form of human activities, vacant land, build-able area etc. most accurately, effectively, and easily. Needless to mention that this paper can be expanded to depict the up-to-date picture, if there is a need and if information is available in respect of satellite images.

\section{BACKGROUND}

The effectiveness of information on urban changes for planning and management decision-making, particularly in developing countries, depends upon the availability of useful data. Detecting evolutions in land cover/use requires detailed surveys, in order to deal with built-up objects and also covering a large area enabling the identification of changes in the outskirts. Common terrestrial or remotely sensed data (map, aerial photography, satellite imagery, etc.) may obviate these problems, providing temporally and spatially detailed information on urban changes (location, type of urban structure). Several authors attempt to better observe and define change features using remotely sensed data [25]; [37] presents very clearly the issues in change detection methods. $\mathrm{He}$ reviews the numerous algorithms that have been developed: multi-date composite image change detection [11]; [13], image change algebra detection [17], image regression [21];[38], manual on-screen digitisation of change [24]; [26];[42] or postclassification comparison detection change [35]. As noticed by [22], the selection of an appropriate change detection algorithm is very important. Different methods introducing fuzzy logic, neural networks [18] or knowledge-based vision systems [15]; [42] have also been tested to define the likelihood of changes detected from remotely sensed data. Metternicht [31] proposes a standard procedure using fuzzy sets and fuzzy logic, whereby the membership function of the fuzzy model can be adapted to identify the areas that have undergone change during the period of observation. Lo' pez, Bocco, Mendoza and Duhau [27] base their study on the Markov transition matrices to predict land cover and land use change in the city of Morelia (Mexico). For instance, the authors found that using the relationship between urban growth and landscape change, the highest land cover/use indicators are the built-up areas.

As these take the form of informal settlements in developing countries, they are rather technically delicate to observe on high resolution satellite images (with spatial 
resolution around $20 \mathrm{~m}$ ) due to their built-up specificities: derelict areas, pattern of buildings, size of the elements, density of the areas, building material (e.g. plastic and metal sheeting), age of the settlement. All of these complicate greatly the identification of these areas. Moreover, the differentiation of the informal settlement functions (housing function or industrial function) is difficult at these resolutions. Nevertheless, in such environment, informal settlement patterns are easy to recognize according to the absence (or little presence) of planning structure, the density of the housings and the seldom vegetation.

Other approaches in change location estimation may be proposed using interaction models. They offer the capacity to specify the intensity of the influence between two locations, what Abler, Adams and Gould [1] called the "underlying interactions among places". The potential model defines among the locations the commonalities between land cover/use categories. One of the interesting results is a surface of interaction that maps the reciprocal influences of each point located in a defined area [39]. Numerous applications have been done using common sets of data and were applied successfully for a long time in demographic, geographic or economic studies to define the interactions between located phenomena [2];[8];[9].

Finally, spatial information and remotely sensed data are particularly helpful in providing time-series information on urban landscape evolutions; coupled to potential model applications, they provide interesting supports for planning purposes.

\section{STUDY AREA, IMAGERY AND REFERENCE DATA}

\subsection{Description of the Study Area}

The research was carried out in the southwestern part of the Metropolitan Area of Tunis (MAT). Tunisia, with its 9 million inhabitants, experienced a significant urban growth over the past 30 years, much like the majority of Mediterranean countries. This growth is particularly clear in the capital, Tunis, even if other large cities of the country (Sfax, Gabe`s with more than 400000 inhabitants) have also been affected by this growth.

Located at the bottom of the gulf of Tunis, the MAT (Fig. 1), with about 2 million inhabitants and an annual growth of approximately 3\%, is the economic and administrative capital of Tunisia. The current administrative perimeter of this metropolitan area is composed of four administrative sectors (Ariana, Tunis, Ben Arous and Manouba) which have experienced an extension of 350000 ha in 1998 against 150000 ha in 1975 . The MAT has had an important increase of informal settlements, especially in its southwestern part due to the institutional lack of capacity to provide affordable housing to the population. This caused significant changes in the urban structure during the last two decades.

Several historical and geographical characteristics explain the trends of this urban development. Historically, the first generation of informal settlements in the southwest periphery of the capital occurred between 1930 and 1950, as a result of rural migration flows following the agricultural crisis and the dryness of the years 19441947. From its independence (in 1956) to the beginning of the 1970s, this continual rural-to-urban flow has strongly increased the urban population of Tunis, and since 
1975, the population growth is mainly the result of an endogenous growth and the migration from the average cities (Sousse, Bizerte with more than 200000 inhabitants) to the capital.

Geographically, the development of the MAT has occurred under the influence of several physical constraints. Indeed, it has grown in a hilly context and large water surfaces such as the Tunis Lake, the Sebkha Ariana in the northeast and the Sebkha Se'joumi in the southwest (Fig. 1). The two significant components of the study zone are the Sebkha Se'joumi and agricultural zones.

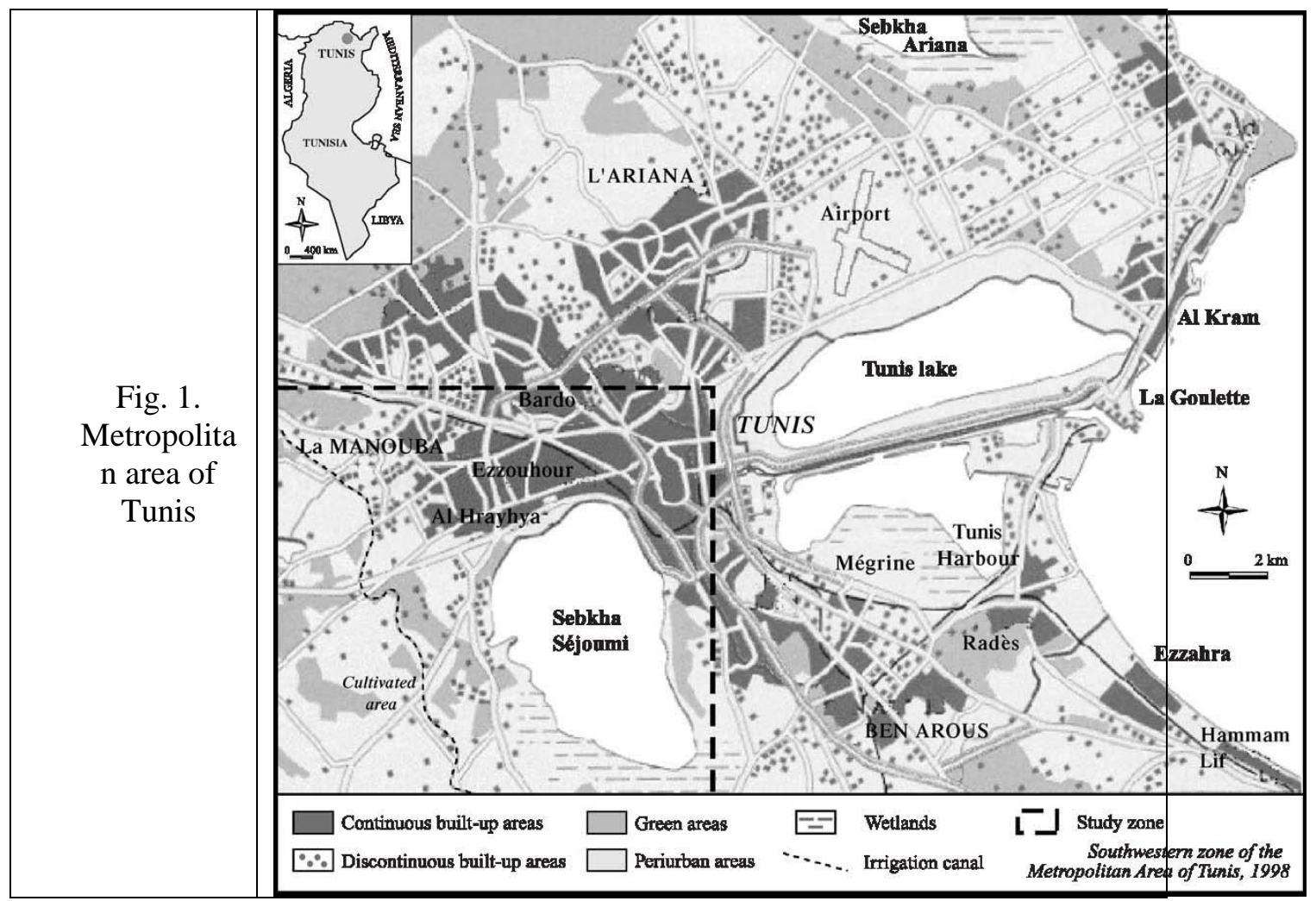

The Sebkha Se'joumi is a salted lagoon of variable extension (up to $28 \mathrm{~km}$ ) where the water level and depth are variable. During average rainfall years, the Sebkha Se'joumi is drained 5 months per year (from May to September-October). The agricultural zones are composed of non-irrigated oleiculture and arboriculture on the hills and of annual cultures and fruit arboriculture in the fertile plain. The plain is strongly "human-made" by a dense irrigated network. The most significant is the Me' jerda-Cape Bon canal, which crosses the zone from the north to the south (Fig. 1).

The developments of informal settlements in these fragile lands pose very serious problems to the local authorities, which have difficulties in controlling this extension. In 1994, an initial planning document (Urban Management Plan of the southwest of Tunis) was adopted to protect the natural area (Sebkha Se'joumi and its banks) and to preserve the agricultural zones around the Me'jerda Cape Bon irrigation 
canal. This development in the southwestern part of MAT actually remains the main settlement location now and for the forthcoming future.

\subsection{Imagery and Reference Data}

The imagery used for this research consisted of multispectral data of two SPOT 3 scenes acquired on March 21, 1986 and May 8, 1996. As the zones around the Sebkha demonstrate major problems in the urban growth, they have been particularly analyzed in this research. Both images are already rectified (2B level). The May image allows a good separation between major land cover classes (water, urban, irrigated and nonirrigated fields) while the early season of the March image makes the separation between the agricultural classes more difficult. Additional terrestrial reference data (topographic map and ground references collected in previous works) were used for classifier training.

\section{METHODOLOGY}

The assessment of the evolution trends of the southwestern part of the MAT has been carried out in two phases (Fig. 2). Firstly, the evolution trends of the built-up areas have been defined by a step-by-step methodological approach and a potential model has been calibrated (weights choice) to locate the built-up growth during the period 1986-1996. Secondly, the potential model has been applied to predict the future locations of land changes for the period 1996-2006.

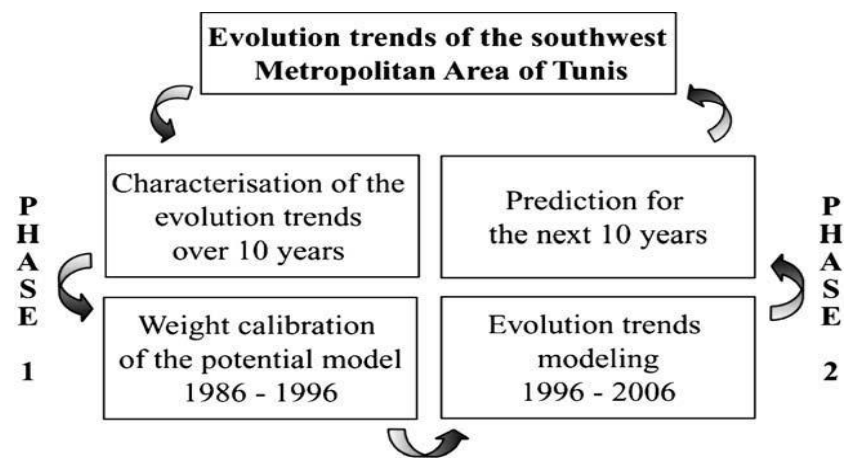

Fig. 2. Methodology flowchart

\subsection{Classification Procedure to Characterize the Land Covers Changes}

As the study zone presents a great variability of non-urban (irrigated and non irrigated crops, arboriculture, natural vegetation) and urban surfaces (high and low density builtup areas), a Principal Component Analysis (PCA) has been applied to extract and classify the land cover categories (Fig. 3). This process allows the reduction of redundant information in the three highly correlated SPOT bands [21] by transforming the correlated variables (XS1 to XS3) into new variables called components (CP1 to CP3). These decorrelated components are useful to improve the classification procedure [3];[33].

The method used to classify the study zone is a supervised classification by 
stepwise discriminate analysis. This process allows to assess in an optimal way the position of a pixel compared to the boundary line between two or more predefined groups. It searches to place the pixel for which the intergroup variance is maximal and the intragroup variance is minimal.

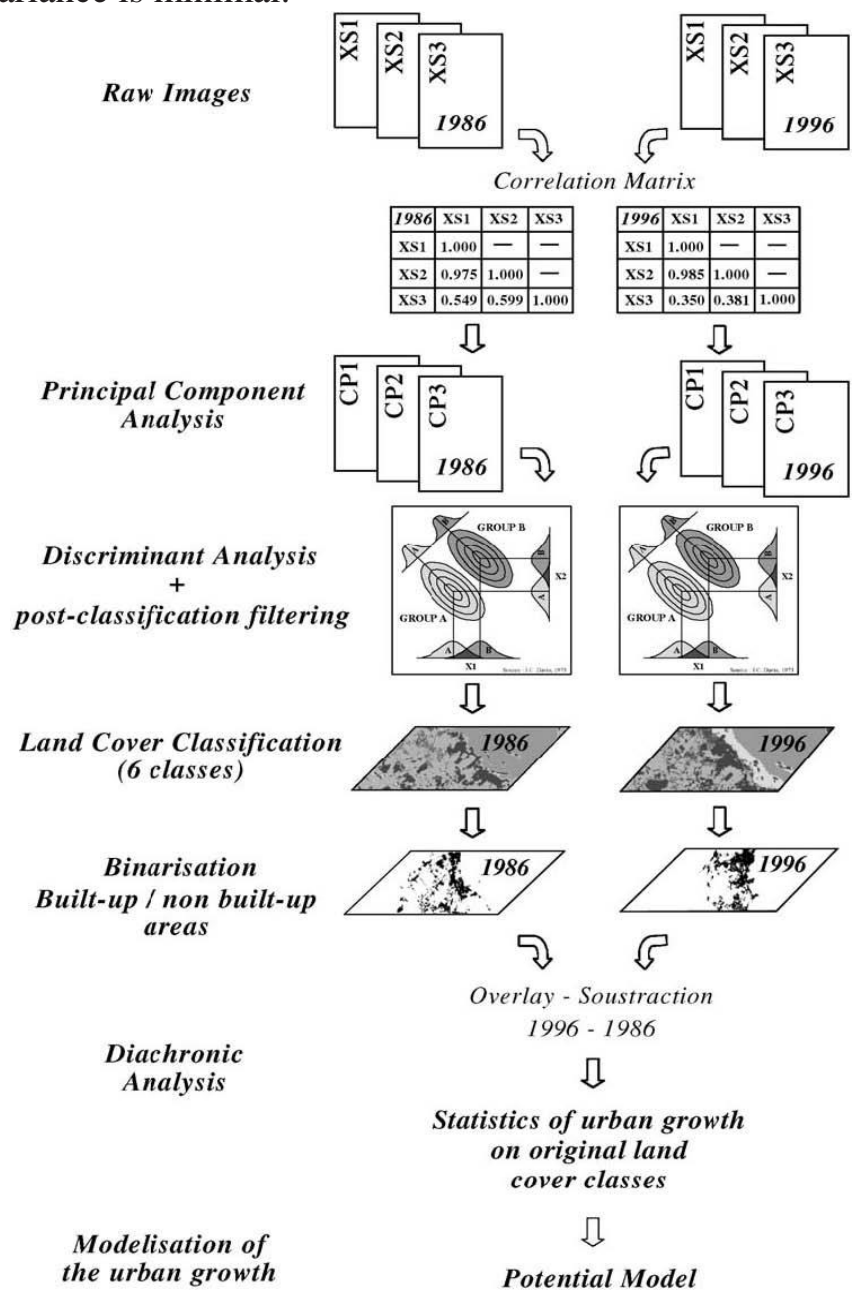

Fig. 3. Methodological approach to characterize the land cover changes between 1986 and 1996.

The result is an image classed by several themes. The accuracy of the classification is around 89\% in 1986 and 93\% in 1996. A post classification treatment entailing the use of a $3 \mathrm{X} 3$ filter has been applied on both images to eliminate the isolated pixels [23].

The land cover categories are then integrated in a Geographical Information System (Idrisi 3.2) and several spatial analysis procedures were used to calculate:

- The built-up areas in 1986 and 1996 (obtained through the binarisation of the built-up categories);

- $\quad$ The built-up growth between 1986 and 1996 (obtained by an overlay operation 
between the built-up and non-builtup areas);

- The original land cover categories of the built-up areas increasing between 1986 and 1996 (obtained by an overlay operation between the urban growth and the original land cover classes of 1986).

The Urban Morphological Area (UMA) has been delimited following the definition of [12] to define the type of urbanization process. The UMA corresponds to the contiguous built-up areas and regroups settlements separated by a distance of less than $200 \mathrm{~m}$ [46]. The delimitation of this area has been realized by a buffer operation within the GIS.

\subsection{POTENTIAL MODEL}

Interaction models and especially the potential model have often been used for demographic or social purposes, in order to study the relationships between population types and locations or between users and goods. Several authors have proposed the application of such a model on remote sensing products to obtain urban delimitation and to define the interactions between space characteristics [2];[7].

Another use of the potential model has been proposed by [46] to evaluate development trends of urban settlements over the years. The more interesting results of this model are to locate the possible development areas of the cities. The potential model allows to locate these changes in relation to natural constraints or "manmade" decisions; such an approach offers the possibility of integrating different types of interactions between various locations.

To apply the potential model, it is necessary to admit postulates[30]:

- There are some interactions between all pixels characterized by their weights (mij) and their localization;

- The interaction probability is the same for all pairs of pixels;

- The intensity of the interaction is inversely proportional to the distance (dij).

Distances (dij) are defined through Cartesian measurements on a regular grid, and weights (mij) reflect the land cover categories of area. When specific weights are adapted to land cover types, variations in the interactions according to others factors (weights of political decision, resistance of agricultural areas, protection of natural zones...) are introduced. The equation of the potential model is given by:
Table 1 Land cover classification categories

\begin{tabular}{|c|c|c|}
\hline Categories & Class & Description \\
\hline \multirow[t]{4}{*}{ Built-up areas } & High density built-up & Inner-city and continuous \\
\hline & area & built-up areas \\
\hline & Low density built-up & Discontinuous built-up \\
\hline & area & areas \\
\hline \multirow[t]{4}{*}{ Agricultural areas } & Spontaneous vegetation & Trees, mixed vegetation \\
\hline & or arboriculture & $\begin{array}{l}\text { type, oleiculture, } \\
\text { arboriculture }\end{array}$ \\
\hline & Irigated or annual & Fodder plants, leguminous \\
\hline & crops & \\
\hline \multirow[t]{6}{*}{ Natural areas } & Sebkha & Large salted lagoon \\
\hline & & (considered as a \\
\hline & & natural reserve) \\
\hline & Wetlands & Undifferentiated \\
\hline & & wetlands (bare soils \\
\hline & & around the Sebkha) \\
\hline
\end{tabular}




$$
P_{i}=\sum_{\substack{j \neq i \\ j=1}}^{n} m_{i j} /\left(d_{i j}\right)^{b}+m_{i j}\left(1 / 2 \sqrt{S_{i}} / \pi\right)^{b}
$$

Where $\mathrm{Si}$ corresponds to the area of the pixel I [30]

The above formalization corresponds to the simplest form of the model. It can be sophisticated by adding external parameters (such as land ownership registration). In this study, this parameter has not been taken into account because the proximity of urban core and road networks seems to be relevant and sufficient to locate development trends which might occur in future.

More precisely, in a first step, two different potentials (an urban potential A corresponding to the situation of the built-up areas at a time $t$ and an urban growth potential B corresponding to the trends of development of the built-up areas observed at the time $t+1$ ) are calibrated and combined to identify the real expansion of built-up areas over the period 1986-1996. The calibration parameters (i.e. the weights for the both potentials) are defined by a trial and test procedure to match the real development over the period 1986-1996. The weight values have to be ordered to give the best results [32]. They are calibrated with value scales from 0 to 10 in order to obtain results, where interaction intensities have value scales between 0 and 200 [44];[46].

Then, in a second step, the same calibration parameters are applied over the period 1996-2006 to predict the location of the evolution trends of urban growth. This has to be considered with the hypothesis that the characteristics of the growth will stay identical for the two periods.

\section{RESULTS AND DISCUSSION}

\subsection{Evolution of the Land Cover}

The supervised classification allows the identification of six land cover categories, detailed in Table 1. Globally, the percentages of the agricultural lands decrease between the both dates and the natural lands remain identical (Table 2). Fig. 4a and $b$ show that in May 1996, the identification of a wider surface of Sebkha compared to the 1986, March image is due to exceptional rainfall conditions during the winter 1996.
Table 2 Repartition of the land cover categories in 1986 and 1996

\begin{tabular}{|c|c|c|c|c|c|}
\hline & Class & Surfac & 1986 & Surfac & 1996 \\
\hline & & ha & $\%$ & ha & $\%$ \\
\hline $\begin{array}{l}\text { Agricultural } \\
\text { lands }\end{array}$ & $\begin{array}{l}\text { Spontaneous } \\
\text { vegetation } \\
\text { or arboriculture }\end{array}$ & 1246 & 16 & 1011 & 13 \\
\hline & $\begin{array}{l}\text { Irrigated or annual } \\
\text { crops }\end{array}$ & 3188 & 41 & 2410 & 31 \\
\hline Natural lands & Sebkha & 1240 & 16 & 1399 & 18 \\
\hline & Wettands & 469 & 6 & 313 & 4 \\
\hline Built-up areas & $\begin{array}{l}\text { Low and high } \\
\text { densities }\end{array}$ & 1633 & 21 & 2643 & 34 \\
\hline
\end{tabular}


Some confusion exists in the repartition of the agricultural and natural land cover categories because the vegetation is not in the same phenologic phases in the March 1986 and May 1996 images. Moreover, the poor radiometric quality of the image in 1986 contributes also to the confusions between these two types. We can also note that the built-up areas in the 1986 land cover classification are overestimated in the southwestern part of the study zone due to some confusion with quarries, which appear with the same spectral response. These confusions are taken into account in the interpretation of the change detection results.

\subsection{Quantification of the Land Cover Changes and Identification of the Expansion Processes}

In a first step, the total urban growth is quantified and located on the binarised images of the built-up areas (Fig. 4c and d). They reveal a global increase of 1010 ha of builtup areas, in the period 1986-1996 (about 13\% in 10 years).

Most of the growth occurred in the western direction along Table 2 Repartition of land cover categories in 1986 and 1996 roadway network andante south direction along the Sebkha (Fig. 5a). The explanation of the growth cannot be deduced from the images which only allow locating the expansion. Nevertheless, other studies give some explanations on the reasons of this growth [10];[14].

On the one hand, the progression in the western direction can be related to the congestion and the increase of dwelling costs in the inner city. These surfaces are attractive to the population because of their proximity to the capital. On the other hand, the growth along the Sebkha can be explained by the recent implementation of industrial infrastructures. A north/south road near the banks of the Sebkha has improved their location. Surprisingly, these zones are recorded as industrial lands in the latest Master Plan [10].
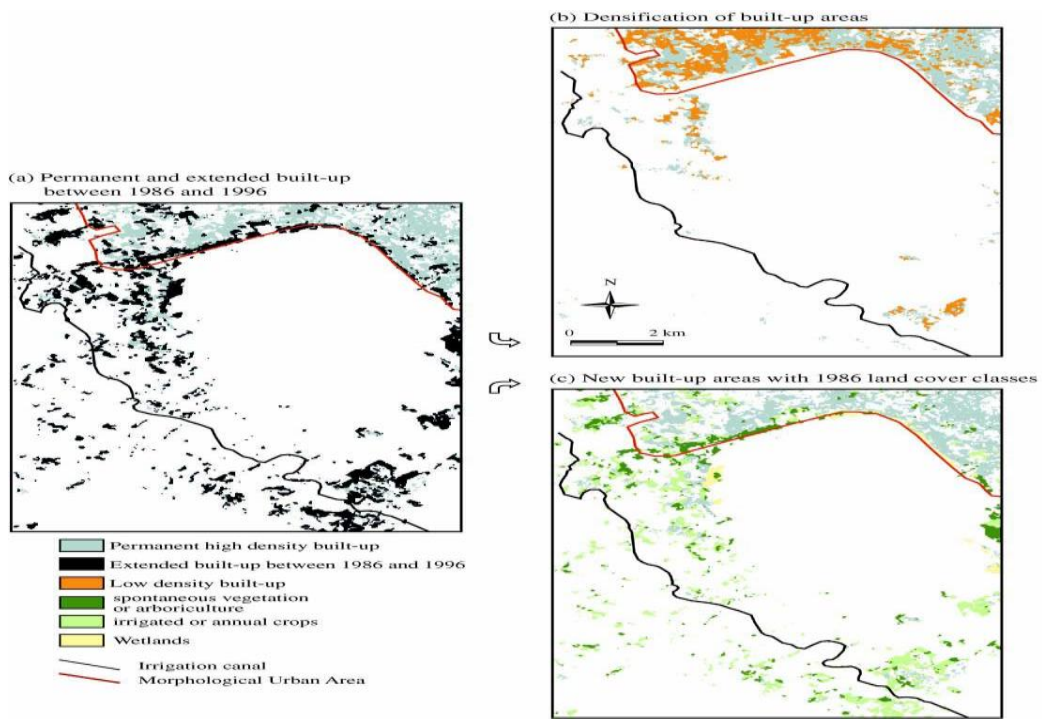

Fig. 4. Land cover classification in 1986 (a) and 1996 (b) and extension of the built-up areas (binarisation process) in 1986 (c) and 1996 (d). 

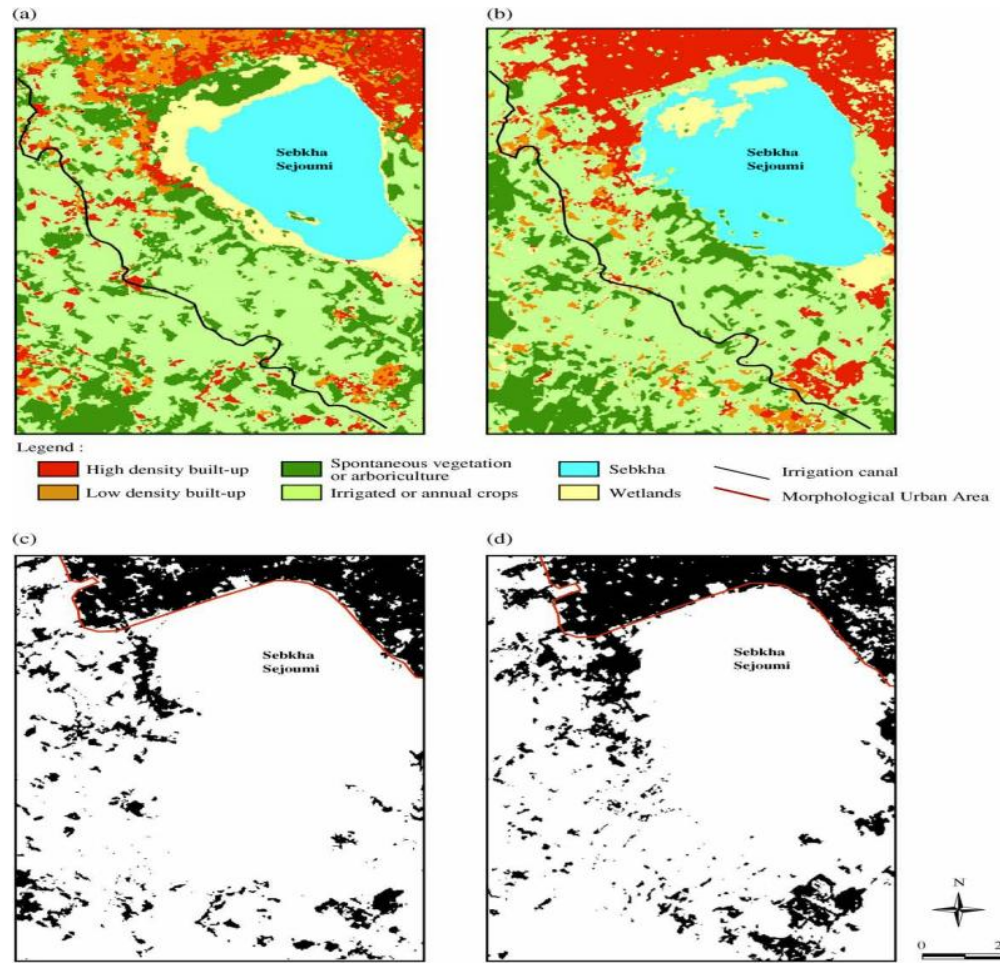

Fig. 5. Localization of the urban growth and its extension on the original land cover categories.

In the South, the urban growth is homogeneous around old village centres [14]. All these indications are taken into account in the following paragraph to simulate the trends of development. In a second step, from the overlay operation between the built-up extension and the 1986 land cover categories (Fig. 5a and c), two builtup extension processes can be identified (Table 3):

(1) A densification of low density built-up areas (formal settlements planned by urban policies);

(2) An apparition of new built-up areas largely unplanned (so-called informal settlements, Fig. 5b).
Table 3 Urbanization processes between 1986 and 1996

\begin{tabular}{|c|c|c|c|c|c|c|c|}
\hline \multirow{3}{*}{ Type of urbanization process } & & \multicolumn{6}{|c|}{ Original land cover catcgories (1986) } \\
\hline & \multirow[t]{2}{*}{ he $\%$} & \multicolumn{6}{|c|}{$\begin{array}{l}\text { Spontancous Irigated or Wetlands } \\
\text { vegectation or annual cops } \\
\text { arboriculture }\end{array}$} \\
\hline & & he & $\%$ & ha & $\%$ & ha & $\%$ \\
\hline $\begin{array}{l}\text { (1) Densification of the } \\
\text { low density built-up }\end{array}$ & 354 & & 1 & 1 & 1 & 1 & 1 \\
\hline $\begin{array}{l}\text { (2) New built-up areas } \\
\text { (informal settlements) }\end{array}$ & 656 & & 32 & 397 & 60 & & 8 \\
\hline
\end{tabular}

The densification process (35\% of the growth) occurs at more than $80 \%$ in the Urban Morphological Zone (UMA). The remaining 20\% come from the densification of surfaces in the old villages in the South and along the western side of the Sebkha. 
The new informal settlements (either high or low density) along the Sebkha represent about $65 \%$ of the global growth (Table 3). The function of these settlements (residential type, industrial type) cannot be identified due to the resolution of the images.

Informal settlements extend primarily on agricultural lands and secondarily on natural vegetation zones (Table 4). Over 10 years, they are more and more scattered all around the agricultural areas inducing a progressive reduction of this activity. Natural areas also become more exposed. Such changes are observed in the south around the old settlements which are in full expansion [14], while the evolution of natural vegetation zones are mainly located at the periphery of the UMA and close to the Sebkha.
Table 4 Calibrated weights attributed to each land cover classes

\begin{tabular}{lll}
\hline Class & $\begin{array}{l}\text { Weights "urban" } \\
\text { potential (A) }\end{array}$ & $\begin{array}{l}\text { Weights "urban } \\
\text { growth" potential (B) }\end{array}$ \\
\hline High density buit-up arca & 9 & 1 \\
Low density built-up arca & 7 & 3 \\
Spontancous vegetation or & 1 & 5 \\
arboriculture & & \\
Irrigatod or annual crops & 1 & 6 \\
Schbha & 0 & 0 \\
Wetands & 1 & 1 \\
\hline
\end{tabular}

The multiplication of informal settlements around the agricultural zones and the Sebkha produce several negative impacts on the rural and natural environments. Indeed, their expansion on unsuitable soils not intended for housing, often without any public facilities (sanitary network, water supply), disturb the hydrological system inducing pollution and disappearance of the natural vegetation of the Sebkha [10].

Industrial wastes are also discharged in the Sebkha because many industrial activities have established near the capital and along the road network since the 1980s. A general risk is present with the potential use of the water by the population and the induced imbalance of the lagoon being drained and polluted on the long term.

The mutation of agricultural zones in urban settlements also leads to negative impacts on the environment because the deforested lands become more susceptible to floods. Furthermore, the loss of agricultural zones could incur a decrease in the supply of crops to the population of Tunis.

\subsection{Simulation with the Potential Model}

The potential model has been applied in order to locate the possible urban extension and forecast the development of informal settlements extension in the southwest of the MAT. To remind, the simplest form of the model is applied without the introduction of external data such as land ownership.

In a first step, the multi-criteria weighting procedure (urban potential A and urban growth potential B) is used to calibrate the model taking into account the interactions between the 1986 built-up areas and the constraints associated to the Master Plan in 1996.

A first potential image, so-called "urban'" potential is created. It defines the situation of the built-up area in 1986. Weights are applied to different land cover categories, according to the following constraints defined in the Master Plan (Table 4): 
- High weights for the built-up areas which are already urbanized;

- Low weights for the agricultural and natural areas which have to be preserved (following the Master Plan).

Then, a second potential image, so-called "urban growth" potential, is created by taking into account the real development over the period 1986-1996. The calibration parameters (i.e. the weights) are defined by a trial and test procedure to match the real development over the period 1986-1996 (Table 4):

- high weights for the land cover categories which have known an important growth (hierarchically, the higher weights are attributed to agricultural lands and then to low density built-up areas);

- low weights for the land cover categories in which the growth is not relevant (wetlands and high density built-up areas).

The resulting composite image (combining both potentials), is presented in six classes to enhance the comprehension of the results (Fig. 6a). It highlights the location of the extension growth between 1986 and 1996.

The results show that the calibrated parameters identify the cohesion of the inner city with some concentric halos. The UMA is identified with a high possibility of urban extension. The surfaces along the western banks of the Sebkha and the old villages in the south are identified with a medium potential growth. These observations are in accordance with the extensions of 1996. The results also highlight a possible growth of built-up areas on the agricultural-protected lands.

In a second step, the same weights are applied on the 1996 land cover categories to locate the potential development of the built-up areas for the period 1996-2006 (Fig. 6b). The resulting image highlights the UMA cohesion without any concentric halos. The concentric halos with high potential are localized in the periphery of the old villages in the south and in the west of the UMA along the EastWest road.

It can be expected that these old villages will have a significant growth in the near future. The other sensitive zones are located in the southwest where some spontaneous vegetation could be exposed to a future urban development. These results can provide to local authorities and other stakeholders indications on the possible evolution of the studied area and may help in decision-making for future planning and monitoring plans.

\section{CONCLUSION}

The phenomenon of informal settlement seems to be a crucial issue to urban development monitoring in the Metropolitan Area of Tunis. Lack of relevant spatial information may be obviated with remote sensing data. Time-series procedures offer some possibilities for steady surveys of land cover changes. The articulation between statistical approaches (supervised classification and post-processing) and potential modeling capacities provides some support in decision-making documents to elaborate future monitoring scenarios. Regarding sustainability issues, this kind of approach may offer useful information on possible exposed land cover categories towards increasing urbanization. In this paper, we have located and quantified the increase of built-up areas in the periphery of the Metropolitan Area of Tunis. The data used (high- 
resolution images with a spatial resolution of $20 \mathrm{~m}$ ) allows only the identification of the extension of the built-up areas. Nevertheless, in order to precise this information and to identify urban objects (for example to distinguish the housing informal settlements from the industrial settlements), very high spatial resolution data (with resolution of less than $5 \mathrm{~m}$ ) has to be used.

(a) Potential growth of built-up in 1996

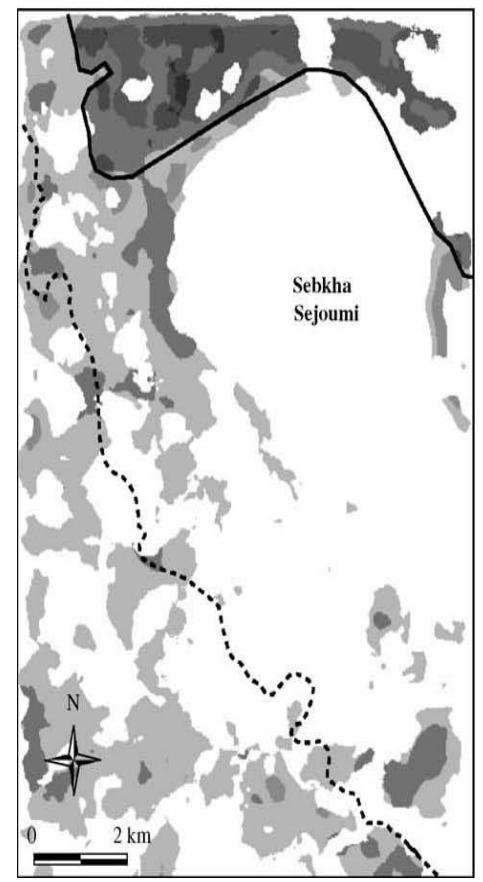

(b) Potential growth of built-up in 2006

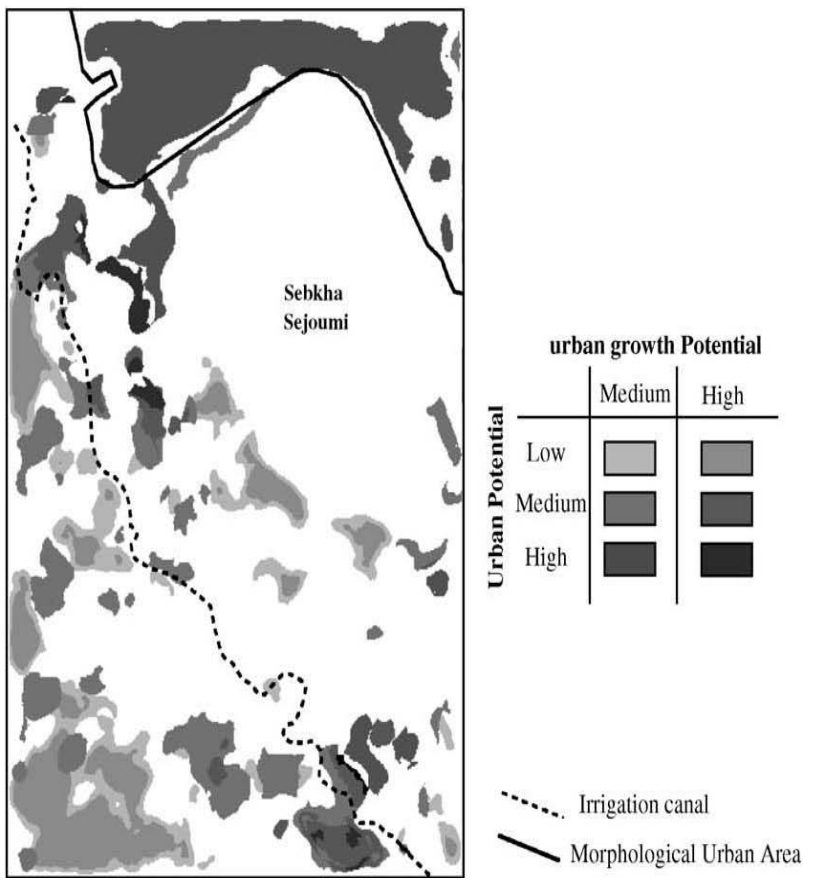

Fig. 6. Localization of the potential urban growth in 1996 and 2006.

Moreover, the both identified urbanization processes can have environmental impacts over agricultural and natural areas. The most relevant process is the transformation of protected agricultural areas by the multiplication of informal settlements. Then, the built-up areas increase and densify the UMA along the Sebkha. All these extensions risk to disturb the environment by increasing poor housing conditions, uncollected solid waste, over-consumption of freshwater supplies, soil pollution, erosion and loss of cultivated lands.Finally, the potential model appears to be a useful tool to model the urban growth and to produce supports highlighting the future development trends of metropolitan areas. It is expected that this method could be applied elsewhere. The model can also be improved by additional information such as land ownership registration.

\section{ACKNOWLEDGEMENTS}

The author would like to express his appreciation to the DAAD which gave him this opportunity through a scientific scholarship to join the Third world-German group in this research project under the supervision Hanover University (Germany). 


\section{REFERENCES}

[1] Abler, R., Adams, J., \& Gould, P. (1972). Spatial organization. New York: Prentice Hall International Editions, 587 pp.

[2] Binard, M., Nadasdi, I., Lambinon, M., Marchal, D., \& Donnay, J. P. (1995). Etudes multi-e'chelles: Applications aux agglome'rations du nord-ouest de l'Europe. Te'le'de'tection des milieux urbains et pe'ri-urbains (pp. 15 -23). AUPELF, Presses de l'Universite' du Quebe'c.

[3] Bonn, F., \& Rochon, G. (1992). Pre'cis de te'le'de'tection, vol. 1: Principes et me'thodes. Sainte-Foy: Presses de l'Universite' du Que'bec, Montre'al: AUPELF, 485 pp.

[4] Bounfour, A., \& Lambin, E. (1999). How valuable is remotely sensed information? The case of tropical deforestation modelling. Space Policy, 15(3), $149-158$.

[5] Chen, X. (2001). Using remote sensing and GIS to analyse land cover change and its impacts on regional sustainable development. International Journal of Remote Sensing, $1-18$.

[6] Dale, V. H., Southworth, F., O’Neill, R. V., Rosen, A., \& Frolin, R. (1993). Simulating spatial patterns of land use changes in Rondonia, Brazil. Lectures on Mathematics in the Life Sciences, pages 23, $29-55$.

[7] Donnay, J. P. (1994). Agglome'rations morphologiques et fonctionnelles, l'apport de la te'le'de'tection urbaine. Acta Geographica Lovaniensia, 34, 191- 199.

[8] Donnay, J. P. (1995). De'limitation de l'hinterland des agglome'rations urbaines au de' part d'une image de te'le'de'tection. Revue Belge de Ge'ographie, 119, 325 -331 .

[9] Donnay, J. P., \& Lambinon, M. (1997). De'termination des limites de l'agglome'ration par te'le'de'tection: Discussion me'thodologique et application au cas de Huy (Belgique). Te'le'de'tection des milieux urbains et pe'riurbains (pp. 239 -246). AUPELF, Presses de l'Universite' du Que'bec.

[10] Drissi, E. (1997). La dynamique urbaine dans la zone ouest de Tunis: Arrondissement de Sidi H'Cine-Apport de la te'le'de'tection spatiale. Me'moire de DEA. Strasbourg: Faculte' de Ge'ographie et d'Ame'nagement, Universite' Louis Pastreur, 90 pp.

[11] Eastman, J. R., \& Fulk, M. (1993). Long sequence time series evaluation using standardized principal components. Photogrammetric Engineering and Remote Sensing, 59, $991-996$.

[12] Eurostat (1994). Te'le'de'tection et statistiques urbaine. Programme Te'le'de'tection, Luxembourg.

[13] Fung, T., \& LeDrew, E. (1987). Application of principal components analysis for change detection. Photogrammetric Engineering and Remote Sensing, 53, 1649 1658.

[14] Gammar, M., Aouni, L., \& Bouassida, L., (1995). Suivi de la dynamique urbaine de l'agglome'ration de Tunis. Cahiers du GDTA (pp. $104-116)$, Te'le'de'tection, Urbanisme et Ame'nagement.

[15] Gong, P., Pu, R., \& Chen, J. (1996). Mapping ecological land systems and [16] classification uncertainties from digital elevation and forest-cover data using 
neural networks. Photogrammetric Engineering and Remote Sensing, 62, 1249 1260.

[17] Green, K., Kempka, D., \& Lackey, L. (1994). Using remote sensing to detect and monitor land-cover and land-use change. Photogrammetric Engineering and Remote Sensing, 60, 337.

[18] Halls, P. J., Polack, F., \& Keefe, S. (2000). A new approach to the spatial analysis of temporal change using todes and neural nets. Cybergeo ( 9 pp.).

[19] (http://www.cybergeo.presse.fr/dwham/polack/polack.htm)

[20] Jensen, J. R. (1983). Urban/Suburban Land Use Analysis. In R. N. Colwell (Ed.), Manual of remote sensing (2nd ed.) (pp. 1571 -1666). Falls Church, VA: American Society of Photogrammetry.

[21] Jensen, J. R. (1986). Introductory digital image processing. A remote sensing perspective, vol. 379 (pp. 169 -173). Englewood Cliffs, NJ: Pren-tice-Hall.

[22] Jensen, J. R. (1996). Introductory digital image processing - a remote sensing perspective (2nd ed.). Englewood Cliffs, NJ: Prentice Hall.

[23] Jensen, J. R., Cowen, D. J., Althausen, J. D., Naramalani, S., \& Weatherbee, O. (1993). An evaluation of coastwatch change detection protocol in South Carolina. Photogrammetric Engineering and Remote Sensing, 59(6), 1039-1046.

[24] Lacy, R. (1992). South Carolina fines economical way to update digital road data. Gis World, 5(10), 58-60.

[25] Lambin, E. (1996). Change detection at multiple scales: Seasonal and annual variations in landscape variables. Photogrammetric Engineering and Remote Sensing, 62, $931-936$.

[26] Light, D. (1983). The national aerial photography program: A geographic information system resource. Photogrammetric Engineering and Remote Sensing, $59,61-65$.

[27] Lo'pez, E., Bocco, G., Mendoza, M., \& Duhau, E. (2001). Predicting land-cover and land-use change in the urban fringe. A case in Morelia City, Mexico. Landscape and Urban Planning, 55(4), 271 -285.

[28] Loveland, T. R., Merchant, J. W., Ohen, D. O., \& Brown, J. F. (1991). Development of a land closer characteristics database for the conterminous US. Photogrammetric Engineering and Remote Sensing, 57, 1453- 1463.

[29] Mason, S., \& Ru“ther, H. (1997). Investigation of the Kodak DCS460 digital camera for small-area mapping. Journal of Photogrammetry and Remote Sensing, $52,202-214$.

[30] Meinke, D. (1970). Gravitations-und Potentialmodelle. Handwo“rterburch der Raumforschung und Raumordnaug (pp. 1048 -1060). Akademie feur Raumforschung und Landesplanung.

[31] Metternicht, G. (1999). Change detection assessment using fuzzy sets and remotely sensed data: An application of topographic map revision. Journal of Photogrammetry and Remote Sensing, 54(4), 221 -233.

[32] Nadasdi, I., Binard, M., \& Donnay, J. P. (1991). Transcription des usages du sol par le mode le de potentiel. Mappemonde, 3, 27 -31.

[33] Robin, M. (1995). La te'le'de'tection. Paris: Nathan Universite'. 318 pp.

[34] Romero, H., Ihl, M., Rivera, A., Zalazar, P., \& Azocar, P. (1999). Rapid urban growth, land use changes and air pollution in Santiago, Chili. Atmospheric 
Environment, 33, $4039-4047$.

[35] Rutchey, K., \& Velchneck, L. (1994). Development of an everglades vegetation map using a SPOT image and the Global Positioning System. Photogrammetric Engineering and Remote Sensing, 60, 767-775.

[36] Ru"ther, H., Martine, H., \& Mtalo, E. G. (2002). Application of snakes and dynamic programming optimisation technique in modelling of buildings in informal settlement areas. Journal of Photogrammetry and Remote Sensing, 56, $269-282$.

[37] Sailer, C. T., Eason, E. L. E., \& Brickey, J. L. (1997). Operational multispectral information extraction: The DLPO image interpretation program. Photogrammetric Engineering and Remote Sensing, 63, 129 - 136, 159-160.

[38] Singh, A. (1986). Change detection in the tropical forest environment of northeastern India using Landsat. In M. J. Eden, \& J. T. Parry (Eds.), Remote sensing and tropical land management (pp. 237 -254). London: Wiley. C. Weber, A. Puissant / Remote Sensing of Environment 86 (2003) 341-352

[39] Steward, J. Q., \& Warntz, W. (1968). Physics of population distribution. Journal of Regional Science, 1, $99-123$.

[40] Townshend, J. R., Justice, C., Li, W., Gurney, C., \& McMarms, J. (1991). Global land cover classification by remote sensing present capabilities and future possibilities. Remote Sensing of Environment, 35, 243 -355.

[41] UNDP (1991). Human development report 1991. United Nations Development Program, Oxford Univ. Press, Oxford.

[42] Wang, J. (1993). A knowledge-based vision system or detecting land changes at urban fringes. IEEE Transactions on Geoscience and Remote Sensing, 31, 136 145.

[43] Wang, J., Treitz, P. M., \& Howarh, P. J. (1992). Road network detection from SPOT imagery for updating geographical information system in rural-urban fringe. International Journal of Geographical Information Systems, 6, 141 -157.

[44] Weber, C. (1998). La croissance urbaine de Kavala, e'volution et perspectives. SFPT, 151, $29-37$.

[45] Weber, C. (2000). Urban agglomeration delimitation using remote sensing data. GISDATA 9, vol. 8 (pp. 145 -159). Great Britain: Taylor \& Francis.

[46] Weber, C., \& Hirsch, J. (1997). Processus de croissance et limites urbaines. Photo Interpretation, 1-2, $21-33$. 


\section{منهجية نموذج متابعة النمو الحضرى: \\ مثال تطبيقى على منطقة العاصمه التونسيه}

عملية التحضر هي أحد العوامل الرئيسية للتغيير في منطقة البحر الأبيض المنوسط ـ فنجد في السنوات القليلة الماضية ددن تتمو في طريق التحضر ومجتمعات العمرانية الجديدة تحت الإنشاء.

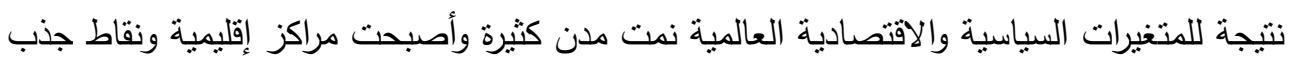
دولية. التحضر وظاهرة المجتمعات الغير مخططه غيرت خارطة استعمالات الأراضي مما أدى التى لتعميق التغيرات الاجتماعية والاقتصادية والبيئية. الهذف الرئيسي من هذه الورقة هو متابعة النطور الزمني للكتلة العمرانية وتحديد مكان واتجاهات تطورها بمنطقة الدراسة في تونس العاصمة . ولذلك سنبدأ باستخدام المرئيات الفضائية من نوع سبوت أكس أس للفترة الزمنية (1986-1996)

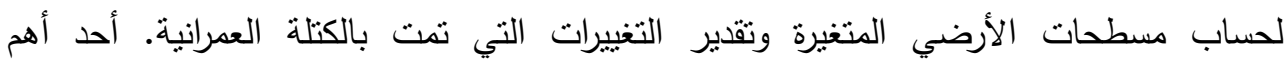
التحليلات هو رصد و تحديد أماكن المناطق العشوائية التي نمت على امتداد شبكة الطرق

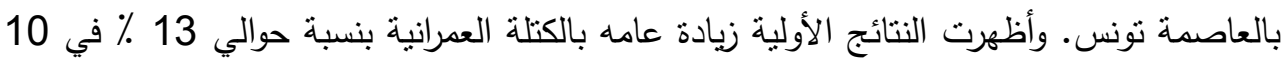

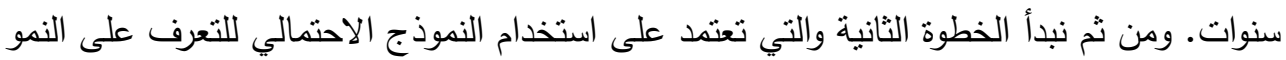

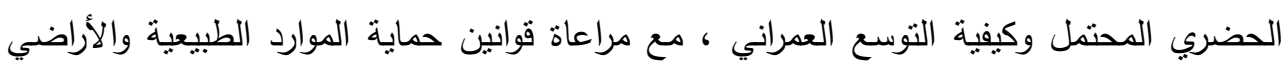
الزراعية.

هذا النوع من النماذج لم يختبر بعد على تطور المدن بهذا النحو ألا أنه يتوافق كليا لدعم

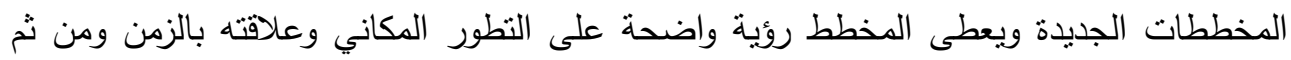
يمكن عمل التوقعات للامتدادات العمرانية المستقلية. بهذه الحالة الدراسية سنقوم بعمل حسابات الامتداد العمراني للفترة من 1986-1996 ، ثم نطبق نتائجها للتتبؤ بمكان واتجاهات النمو العمراني على مدى العشر سنوات النالية (1996 - 2006) كنموذج تطبيقي للمنهجية البحث. هذه النتائج يمكن أن تفيد الإدارات المحلية وغيرها من الجهات المعنية بالمعلومات والوثائق من أجل

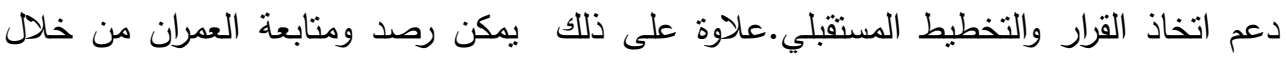
تحديث النموذج بالبيانات الجديدة المنتجة من المرئيات الفضائية حسب توفرها علئي أن أمكن و بصورة 